\title{
半夏厚朴湯の使用目標とその臨床効果との 関連について
}

——機能性ディスペプシア患者における検討——

\begin{tabular}{|c|c|c|c|}
\hline f郎a & 伊藤 & 星野 & 之 $^{\mathrm{ab}}$ \\
\hline 知幸 & 高橋＼cjkstart裕子a & 八代 & 忍 \\
\hline 㙒由佳理 & 小田口＼cjkstart浩a & 花輪 & \\
\hline
\end{tabular}

a 北里大学東洋医学総合研究所, 東京, $\mathrm{T} 108-8642$ 港区白金5-9-1

b 北里大学大学院医療系研究科, 神奈川, $=228-8555$ 相模原市北里1-15-1

\section{Efficacy of Hangekobokuto on Patients with Functional Dyspepsia, with Special Reference to its Clinical Indication and Gastrointestinal Function}

\author{
Tetsuro OIKAWA $^{\mathrm{a}} \quad$ Go ITO $^{\mathrm{a}}$ Takayuki HOSHINO ${ }^{\mathrm{ab}}$

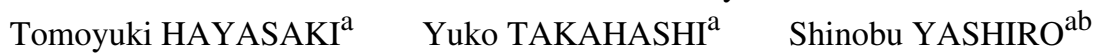 \\ Yukari GONO $^{\mathrm{a}}$ Hiroshi ODAGUCHI $^{\mathrm{a}}$ Toshihiko HANAWA ${ }^{\mathrm{ab}}$ \\ a Oriental Medicine Research Center, Kitasato University, 5-9-1 Shirokane, Minato-ku, Tokyo 108-8642, Japan \\ b Doctoral Program of Medical Science, Kitasato University Graduate School, 1-15-1 Kitasato, Sagamihara-city, Kanagawa
} 228-8555, Japan

\footnotetext{
Abstract

We have limited evidence as to the clinical indications for Kampo medicines, especially as they relate to gastrointestinal function. Thus, we investigated the efficacy of the Kampo medicine hangekobokuto (HKT) on patients with functional dyspepsia (FD), with special reference to its clinical indications for gastrointestinal function, including gastric emptying and bowel gas volume.

Gastric emptying rate (GER) in FD patients was significantly facilitated by HKT. HKT also improved the gastrointestinal symptoms of the patients. Among these, patients who had inchuusharen (咽中多變), or a symptom of globus sensation, and a representative indication for HKT, showed significant improvement of both their GER and gastrointestinal symptoms compared with patients who did not have inchuusharen. As for bowel gas, the bowel gas volume calculated from a plain abdominal radiogram (gas volume score, GVS) in FD patients decreased significantly, after administration of HKT. Patients who had fukuman (腹満), or a feeling that one's stomach is full or bloated, and another representative indication for HKT, showed significant decrease of their GVS to normal levels, compared with patients who did not present with fukuman.

These results suggest that the presence of clinical indications, such as inchuusharen or fukuman, are strongly related to HKT efficacy in patients with FD, and that these are useful, scientifically validated markers for the efficient use of HKT.

Key words : Hangekobokuto, clinical indication, globus, abdominal bloating, functional dyspepsia, gastric emptying, bowel gas

\section{要旨}

漢方薬を運用する際の臨床的な使用目標の科学的妥当性に関し, 消化管機能との関連において記述した報告はほ とんどない。我々は以前より, 半夏厚朴湯が機能性ディスペプシア（functional dyspepsia=FD）患者の消化管 機能に影響を及ぼし, 消化器症状を改善させることを報告してきたが, 今回半夏厚朴湯の使用目標の有無と消化管 機能, 消化器症状の関連について検討した。

FD 患者における胃排出能は, 半夏厚朴湯服用により増加した。このうち, 半夏厚朴湯の代表的な使用目標であ る「咽中多彎」を有する症例では,「咽中多彎」のない症例に比べて, 胃排出能の有意な増加と消化器症状の有意な
} 
改善が認められた。一方腸管ガスについて, 腹部単純レントゲン写真から算出した指標 gas volume score (GVS) は, FD 患者において半夏厚朴湯服用により減少した。このうち，半夏厚朴湯の使用目標のひとつである 「腹満」を有する症例においては,「腹満」を認めない症例に比較して GVS の減少が顕著であった。

これらの結果から，FD患者における半夏厚朴湯の臨床効果は，「咽中多變」や「腹満」といった伝統的に用いら れてきた半夏厚朴湯の使用目標の有無と密接に関連すること, またこれらが科学的妥当性に裏付けられた, 漢方処 方運用における有用な使用目標である可能性が示唆された。

キーワード : 半夏厚朴湯, 使用目標, 咽中多變, 腹満, Functional dyspepsia, 胃排出能, 腸管ガス

\section{緒言}

日常頻用される漢方薬の多くは，消化管への作用 を持つと考えられている。最近になり，機能性ディ スペプシア（functional dyspepsia $=\mathrm{FD}$ ）に対する六 君子湯 ${ }^{122}$ や腸閉塞に対する大建中湯 ${ }^{3)}$, 便秘に対す る大黄甘草湯 ${ }^{4 / 5)}$, 過敏性腸症候群に対する桂枝加䓎 薬湯 ${ }^{6}$ などは比較試験でも臨床効果が証明され，そ の作用メカニズムについても比較的解明されてきて いる。しかしこうした一部の方剤を除いては，まだ 得られている知見は少ない。特に, 漢方医学的所見 や使用目標と関連づけたかたちで，その効果を検討 した報告は極めて少ない。

半夏厚朴湯は金實要略に「婦人咽中多彎有るが如 きは，半夏厚朴湯之を主る」 〕記載されることから， 耳鼻科領域の咽喉頭異常感症によく用いられる他, 気剂として不安神経症などの患者に頻用されてきた。 しかし実際の臨床では，悪心，嘔吐，腹部膨満感と いった消化管症状にも広く応用されている ${ }^{8}$ 。また, 痰飲をさばくために获苓飲合半夏厚朴湯というかた ちでも頻用されるし，妊娠悪阻によく用いられる小 半夏加获苓湯は, 半夏厚朴湯の骨格部分ともいえる 処方である。こうした背景から，これまで我々は胃 もたれなどのいわゆる運動不全症状を訴える FD 患 者における半夏厚朴湯の効果を, その消化管機能に 及ぼす影響を中心に検討してきた。その結果, 半夏 厚朴湯が臨床症状を改善させるのみならず, 胃排出 能を改善させ9), 腸管ガス量を減少させることを 見いだした。

そこで今回我々は, 半夏厚朴湯の臨床症状や胃排 出能, 腸管ガス量と, 半夏厚朴湯の使用目標と考え られている咽中采戀, 腹満の有無とどのような関連 があるのか，検討を行った。

\section{方法}

1. 対象

ローマII 基準 ${ }^{11}$ の食後腹部不快症候群に合致する
FD 患者, 延べ30名（男性12名, 女性18名, 平均年 令54.5歳）を対象とした。患者には十分な説明を行 い,インフォームド・コンセントを得た。また，プ ロトコールは北里研究所 (現北里大学) 東洋医学総 合研究所倫理委員会の承認を得た。被験者に, 半夏 厚朴湯エキス (ツムラ，7.5グラム/日）を食前分 3 で 2 週間服用させ，その前後における消化器症状や 検査結果の推移を検討した。

\section{2 . 漢方所見について}

当研究所漢方外来で使用している問診票のうち, 「のどがつかえる」「痰（が絡む）」に症状があると 答えたものを咽中采彎ありとした。あるいは患者が， 「飲み込む時に違和感がある」など咽中采戀と考え られる訴えをした場合もこれに含めた。

腹満については同様に, 当研究所漢方外来で使用 している問診票のうち，「腹が張る」に症状がある と答えたものを腹満ありとした。このほか腹診所見 上，明らかな鼓音を認める場合も腹満ありとして 扱った。

3 . 胃排出能検査

Fujimura $ら^{12)}$, Kusunoki ${ }^{13)}$ の方法に準じ, 体外 式超音波を用いた胃排出能検査を行った。すなわち 早朝空腹時, 被験者に座位でコンソメスープ $400 \mathrm{ml}$ を服用させたのち, 服用 1 分後と服用 15 分後の胃幽 門部横断面積を超音波診断装置にて計測, 下記の式 により胃排出能を算出した。

$$
\text { 胃排出能 }=\frac{\begin{array}{l}
\text { 服用 } 1 \text { 分後の幽門部横断 } \\
\text { 部横断面積 } 15
\end{array}}{\text { 服用 } 1 \text { 分後の幽門部横断 }} \times 100(\%)
$$

4. 腸管ガス量の定量化

Koide ら ${ }^{14)}$ の方法に従い, 腹部レントゲン上の腸 管ガスを定量化（gas volume score $=\mathrm{GVS} ）$ した。す 
a 全体

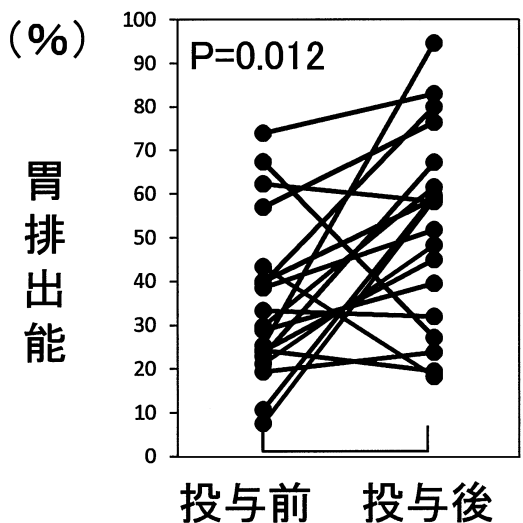

b 咽中多變あり

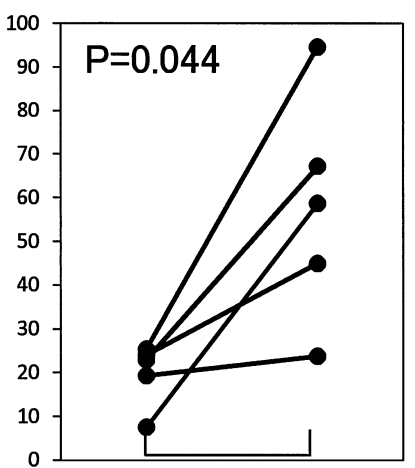

投与前 投与後 c 咽中多戀なし

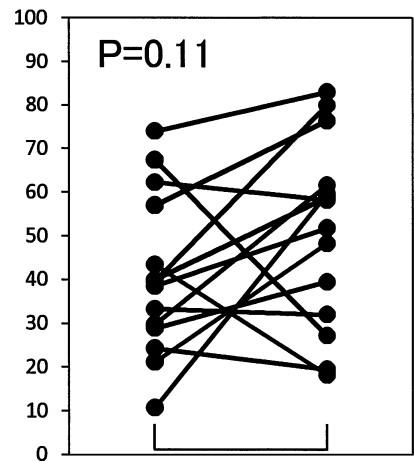

投与前 投与後

図 1 咽中采彎の有無と胃排出能の変化

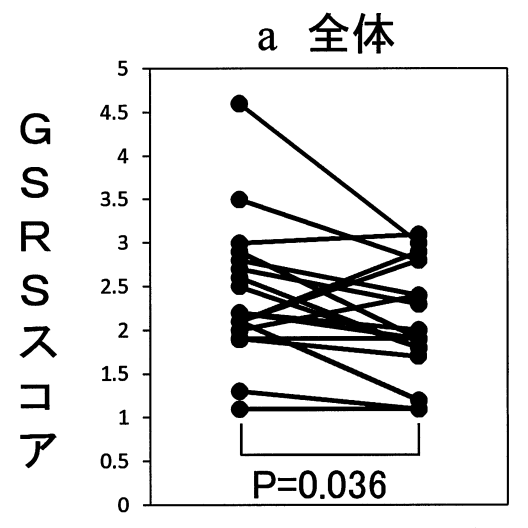

投与前 投与後 b 咽中多變あり

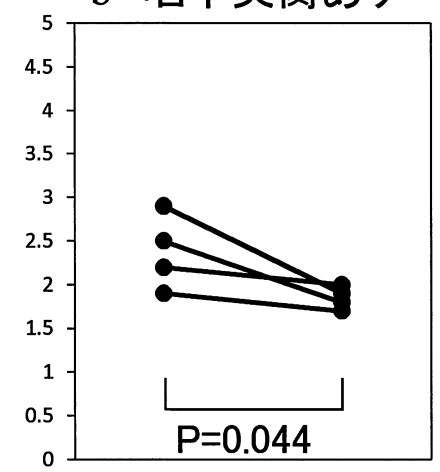

投与前 投与後 c 咽中多戀なし

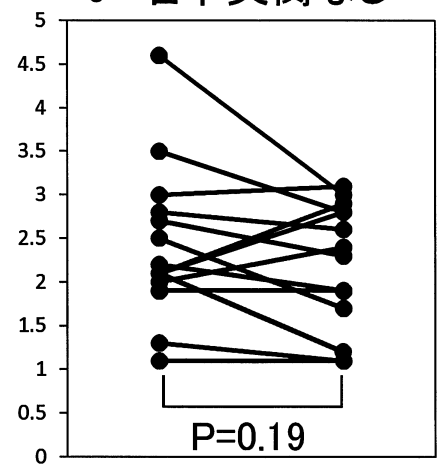

投与前 投与後

図 2 咽中采彎の有無と消化器症状の変化

なわち, 早朝空腹時に仰臥位で撮影した腹部単純レ ントゲン像を画像解析ソフト Scion Image beta上で 処理し, 横隔膜上縁, 左右の胁骨弓外側縁, 恥骨結 合上縁で境される面積を分母, 腸管ガス（胃泡は除 く）の総面積を分子として，下記の式により GVS を算出した。

$$
\mathrm{GVS}=\frac{\text { 腸管ガスに相当する部位の合計ピクセル数 }}{\text { 規定された腹部全体のピクセル数 }}
$$

\section{5. 消化器症状の評価}

機能性消化管疾患によく用いられる QOL 尺度で ある GSRS (Gastrointestinal Symptom Rating Scale) ${ }^{15)}$ を用いて総点数を算出し, 半夏厚朴湯エキス服用前 後における消化器症状の推移につき検討した。

\section{6. 統計について}

データは平均值土標準誤差で示した。2 群間の前 後比較はWilcoxon 順位和検定を行い, $\mathrm{p}$ 值0.05未
満をもって有意差ありとした。

\section{結果}

1. 咽中采變の有無と, 胃排出能を中心とした半夏 厚朴湯の効果

FD 患者 19 名 (男性 7 名, 女性 12 名, 平均年齢 53.3 歳）について検討した。超音波法による胃排出能の 平均値は，半夏厚朴湯エキス投与前35.2（土4.3） \%であったが，半夏厚朴湯エキスを 2 週間投与後 52.8 (土5.1）\%へと有意に増加した（図 1 -a)。 この19名のうち, 咽中采戀を有する患者 5 名と有し ない患者14名を比較すると, 咽中采戀を有する患者 での胃排出能平均值は，19.9（土3.2）％から57.9 （土11.8）\%へと増加し統計上も有意差を認めたの に対し，咽中多戀を有しない患者では40.7（土4.9） \%から51.0（土5.7）\%へと改善したものの, 統計 上の有意差は認めなかった（図 1 -b, 1-c)。

FD 患者の消化器症状は GSRS において, 全体で は半夏厚朴湯エキス投与前の2.38（土0.18）に比較 


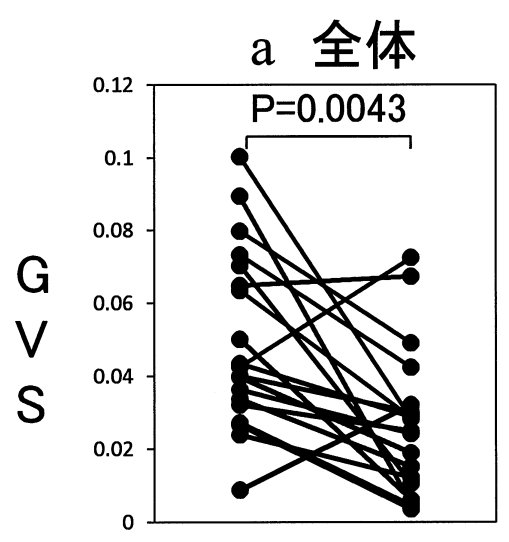

投与前 投与後

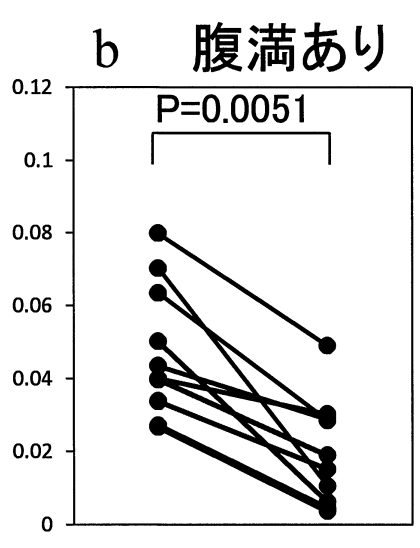

投与前 投与後

図 3 腹満の有無と GVS の変化

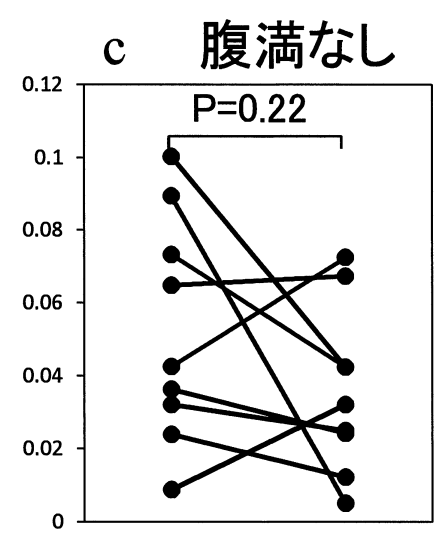

投与前 投与後
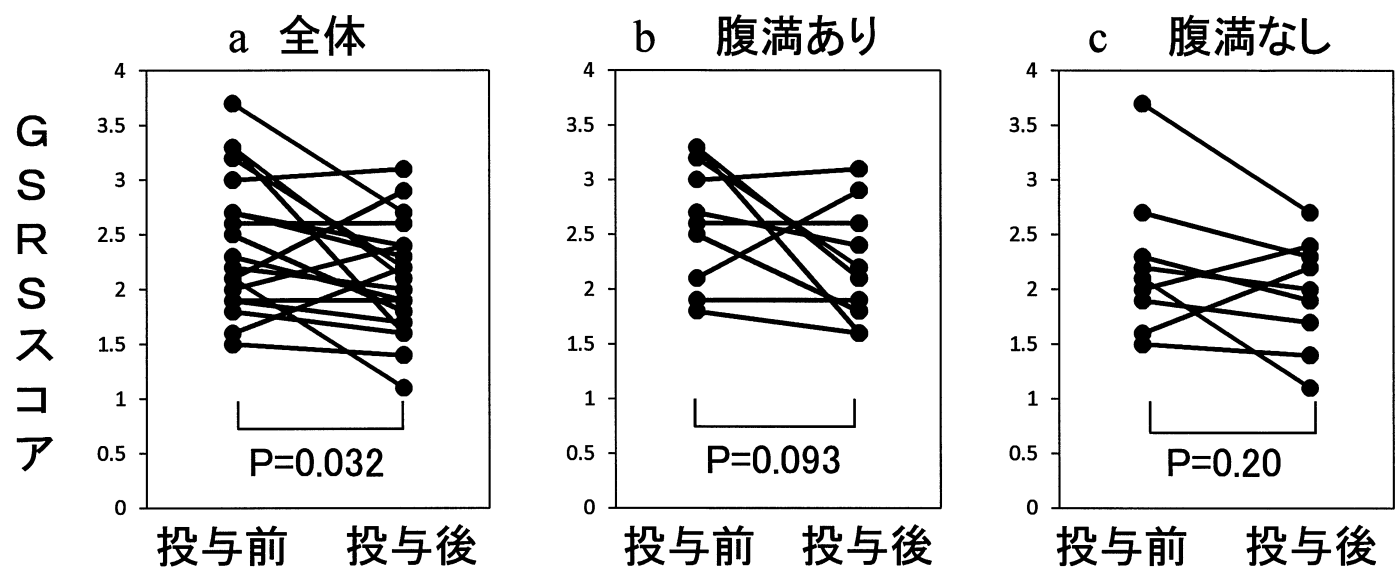

図 4 腹満の有無と消化器症状の変化

し，投与後は2.10（土0.15）と有意に改善した（図 2 -a)。このうち咽中采彎の有無で検討すると, 咽 中多戀を有する患者で2.28（土0.19）から1.82（土 0.06）へと改善し, 統計上も有意差を認めたのに対 し，咽中采戀を有しない患者では2.42（土0.24）か ら2.20（土0.19）へと改善したものの, 統計上の有 意差は得られなかった。(図 2 -b, 2 -c)。

2 . 腹満の有無と, 腸管ガス量を中心とした半夏厚 朴湯の効果

FD 患者19名 (男性 6 名，女性13名，平均年齢50.2 歳）について検討した。FD患者において GVS の 平均值は，半夏厚朴湯エキス服用後0.050 $( \pm 0.006)$ から0.027（土0.004）へと有意に低下した（図 3 a)。この19名のうち, 腹満を有する患者10名と有 しない患者 9 名において検討したところ, 腹満を有 する患者においては服用前と比較して, 服用後の GVS が0.047( \pm 0.006$)$ から0.020（土0.005）へと有 意に低下した。一方, 腹満を有しない患者において
は0.052（土0.010）から0.036（土0.008）へと GVS は減少したが, 統計上は有意差を認めなかった（図 3-b, 3 -c) 。

FD 患者の消化器症状は GSRS において, 被験者 全体では半夏厚朴湯エキス投与前 $2.44( \pm 0.15 ） に$ 比較し，投与後2.10（土0.12）は改善した（図 4 a)。このうち腹満の有無で検討すると, 腹満を有 する患者において2.64（土0.18）から2.22（土0.17） へと改善し, 腹満を有しない患者での改善 $(2.22$ $( \pm 0.22) \rightarrow 1.97( \pm 0.17))$ に比へ, 統計学的有 意差はないものの服用後の消化器症状がより改善す る傾向を示した（図 4-b, 4 -c）。

\section{考察}

漢方薬の臨床的な使用目標の科学的妥当性をどの ように考え, また裏付けていったらよいかは, 現代 医学と漢方医学の双方を学んだものにとっては, 常 に悩みであり課題としてたちはだかる問題である。 消化器領域においては原澤ら ${ }^{1}$ が, 六君子湯の臨床 
効果を評価するサブ解析の項目として腹壁緊張の低 下や腹部振水音, 胃レントゲンに扔ける下垂傾向な ど，漢方医学的な六君子湯の使用目標に近い所見を 取り入れ，こうした所見を有するものに六君子湯の 有効性が高いと結論している。この領域では，これ が漢方薬の使用目標を唯一扱った重要な論文と思わ れる。しかしこの論文を含め, 漢方薬の効果判定に ついては自覚症状の変化によるものがほとんどであ り, 一歩進めて漢方薬服用後の消化管機能にどのよ うな変化があるかという観点から検討，言及してい るものはない。今回は, 漢方薬の使用目標の妥当性 を解明する試みのひとつとして, FD という同一疾 患の患者に対して，半夏厚朴湯という同一処方を投 与した際の治療効果を, 消化管機能検査や有用性が 確認された QOL 尺度など出来るだけ客観的な指標 を用いて判定し, 半夏厚朴湯の使用目標の有無に よってその治療効果に差異があるのかを検証した。 半夏厚朴湯の使用目標として, 今回は金貴要略の記 載以来もっとも代表的な「咽中多彎」と, ガス貯留 など消化管機能とも関連が深いと思われる「腹満」 の 2 つを選択した。

胃排出能は FD 患者で低下していることが報告さ れている ${ }^{16)}$ 。我々も同様の報告をするとともに，半 夏厚朴湯が胃排出能低下を改善させることを見出し ている9 。今回の検討では, 咽中多彎を有する症例 では，有しない症例に比べ胃排出能改善効果が高く, 消化器症状の改善も顕著であることが新たに分かっ た。半夏厚朴湯が胃排出能を改善すること自体は, 半夏, 蘇葉などに腸管運動促進作用がある ${ }^{17) ~ 19) ~ こ ~}$ とや, 胃排出能促進の報告 ${ }^{20}$ がある六君子湯と構成 生薬が類似していることなどからもうなずけるもの であるが，咽中多孌を有する症例でその効果が高い のはなぜであろうか。FDはひとつの疾患単位と なってはいるものの, 現時点ではさまざまな病態生 理を包含した疾患と考えられており, 胃排出能以外 にも内藏知覚過敏や, 適応性弛緩の異常, ストレス や社会心理的要因の関与があげられている ${ }^{11}$ 。咽中 多孌は, 西洋医学的にはヒステリー球と呼ばれる症 状に近く，一般的には自律神経機能の失調を示すと 考えられる。FDの症状には抗精神薬が用いられ る ${ }^{21}$ ことも少なくない現状を考えると, 厚朴など抗 不安効果をもつ生薬を含む半夏厚朴湯が, 自律神経 機能を改善させ不安やストレスの緩和に働くことで,
消化管運動や消化器症状のさらなる改善に寄与して いるものと考えた。半夏厚朴湯が自律神経バランス を改善させることは，すでに若杉らも報告してい る ${ }^{22)}$ 。すなわち半夏厚朴湯が, FD 患者の消化管運 動の促進と自律神経機能の改善という, 複数の病態 生理に同時に作用していると考えるのが妥当ではな いかと思われた。

腹満については, 漢方医学の概念では自他覚的な 腹部膨満, すなわち腹が張るという自覚症状と, ガ ス貯留による腹部の鼓音などの他覚的な所見を包含 している, 西洋医学的にはややあいまいなものと考 えられる。逆に言えば, 腹満の病態生理の少なくと も一部は, 腹部レントゲンなど画像的に捉え評価す ることが可能なのではないかと考えた。今回の検討 では, 腹満を有する症例では有しない症例に比べ半 夏厚朴湯服用後の GVS 減少効果が大きいことが判 明した。腹満を有する症例で GVS 減少効果が大き い理由は何故か。FD患者は, 不安や自律神経機能 の失調を呈するケースが多い。その結果吞気症の傾 向となり，燕下した空気が腸管に貯留し腹満を呈す るものと推察される。半夏厚朴湯には, 動物実験レ ベルでは腸管運動促進作用が示されているので, 上 部と同様下部消化管運動促進効果を有し, 腸管ガス 排出（すなわち腸管ガス減少）に働く可能性があり， 現在この点についてわれわれも検討を進めている。 ただし，腸管ガス量減少を説明できる要因はそれだ けではなく，不安などを抑えて吞気症になるのを防 ぎ，空気の鳏下量を減少させることも大きな理由で はないかと考えられる。半夏厚朴湯が與燕下機能を改 善させるとする報告もある2324)。したがって下部消 化管機能に関しても, FD の惹起する複数の病態生 理に半夏厚朴湯が作用していることが推定された。 西洋医学的には自覚的腹満は bloating, 他覚的腹部 膨満は abdominal distention と比較的はっきり表現が 分かれている。今回の検討では漢方医学の概念に従 い, 腹満の自覚症状と他覚所見を分けなかったが, 今後はそれぞれを個別に解析して両者の差異を検証 することなどを通して, さらに精度の高い研究を目 指したい。

\section{結論}

半夏厚朴湯は, $\mathrm{FD}$ 患者の上部, 及び下部消化管 機能に影響を及ぼし消化器症状を改善させる, 消化 管運動促進薬として作用する可能性が示唆された。 
またその作用は, 咽中采彎や腹満といった半夏厚朴 湯の使用目標に従って用いることで，より強まると 考えられた。古人が積み重ねてきた経験知である半 夏厚朴湯の使用目標は, 少なくとも消化管機能の観 点からは一定の科学的妥当性に裏付けられ, 半夏厚 朴湯を処方するうえで有用であると思われた。

\section{文献}

1 ) 原澤茂, 三好秋馬, 三輪剛ほか : 運動不全型の上 腹部愁訴（dysmotility-like dyspepsia）に対する TJ43六君子湯の多施設共同市販後臨床試験〜二重盲 検群間比較法による検討, 医学のあゆみ，187, 207-229 (1998)

2 ) 三好秋馬, 谷内昭, 正宗研ほか: 慢性胃炎などの 不定の消化器愁訴に対する TJ-43ツムラ六君子湯 の臨床評価〜Cisaprideを対照薬とした多施設比 較試験，Prog. Med., 11，1605-1631（1991）

3 ) 高添正和, 山内浩：クローン病の腸閉塞症状に対 する内科的治療の試み：大建中湯の有用性, 難治 性炎症性腸管障害調査研究班平成 9 年度研究報告 書, 137-141 (1998)

4 ) 三好秋馬, 正宗研, 福富久之ほか：ツムラ大黄甘 草湯エキス顆粒（医療用）（TJ-84）の二重盲検法 による便秘症に対する臨床効果, 消化器科, $\mathbf{1 8}$, 299-312 (1994)

5 ) 三好秋馬, 正宗研, 福富久之ほか：新たな判定基 準によるツムラ大黄甘草湯エキス顆粒（医療用）

（TJ-84）の便秘症に対する臨床効果, 消化器科, 22, 314-328 (1996)

6 ) 佐々木大輔, 上原聡, 樋渡信夫ほか: 過敏性腸症 候群に対する桂枝加药薬湯の臨床効果, 臨床と研 究, 75, 1136-1152 (1998)

7 ) 大塚敬節 : 金實要略講話, 531, 創元社, 大阪 (1979)

8 ) 花輪壽彦: 漢方診療のレッスン, 406, 金原出版, 東京 (1995)

9 ) Oikawa T, Ito G, Koyama H. Hanawa T: Prokinetic effect of a Kampo medicine, Hange-koboku-to (Banxia-houpo-tang), on patients with functional dyspepsia. Phytomedicine 12， 730-734 (2005)

10) Oikawa $T$, Ito G, Hoshino $T$, Koyama $H$, Hanawa $T$ : Hangekobokuto (Banxia-houpo-tang), a Kampo medicine that treats functional dyspepsia. Evid. Based Complement. Alternat. Med., in press.
11) Tack J, Talley NJ, Camilleri M, Holtmann G, Hu P, Malagelada JR, Stanghellini V : Functional gastroduodenal disorders. Gastroenterology 130, 1466-1479 (2006)

12) Fujimura J, Haruma K, Hata J, Yamanaka K, Sumii K, Kajiyama G: Quantitation of duodenogastric reflux and antral motility by color Doppler ultrasonography. Scand. J Gastroenterol. 29， 897-902 (1994)

13) Kusunoki H, Haruma K, Hata J, Hiroshi T, Okamoto E, Sumii K, Kajiyama G : Real-time ultrasonographic assessment of antroduodenal motility after ingestion of solid and liquid meals by patients with functional dyspepsia. J Gastroenterol. Hepatol. 15, 1022-1027 (2000)

14) Koide A, Yamaguchi $T$, Odaka $T$, Koyama $H$, Tsuyuguchi T, Kitahara H et al. : Quantitative analysis of bowel gas using plain abdominal radiograph in patients with irritable bowel syndrome. Am J Gastroenterol 95, 1735-1741 (2000)

15) Glise H, Hallerback B, Wiklund I : Quality of life : a reflection of symptoms and concerns. Scand J Gastroenterol 31 (Suppl 221), 14-17 (1996)

16）楠裕明，春間賢，鎌田智有，本多啓介，古賀秀樹, 武田昌治, 藤村宜憲, 畠二郎：消化管運動異常と FD，診断と治療 93，384-390（2005）

17) Kasahara Y, Saito E, Hikino H : Pharmacological actions of Pinellia Tuber and Zingiber Rhizomes. Shoyakugaku Zasshi 37, 73-83 (1983)

18) Koezuka Y, Honda G, Tabata M : An intestinal propulsion promoting substance from Perilla frutescens and its mechanism of action. Planta Medica 51, 480482 (1985)

19) Yamahara J, Huang Q, Li Y, Xu L, Fujimura H : Gastrointestinal motility enhancing effect of ginger and its active constituents. Chem. Pharm. Bull. 38, 430-431 (1990)

20) Tatsuta M, Iishi $\mathrm{H}$ : Effect of treatment with Liu-JunZi-Tang (TJ-43) on gastric emptying and gastrointestinal symptoms in dyspeptic patients. Aliment. Pharmacol. Ther. 7, 459-462 (1993)

21）苅部正巳：ストレスと FGIDs～心身医学的立場か ら見た FD，IBSの診断と治療〜，診断と治療 93, 419-423 (2005)

22) Wakasugi A, Odaguchi H, Shoda H, Ito H, Gamo Y, 
Hoshino T, Watanabe K, Hanawa T, Differentiation between Hangekobokuto and Kososan based on pupillary dynamics - Evaluation of autonomic nerve function - . J. Trad. Med. 23， 132-140 (2006)

23) Iwasaki K, Wang Q, Nakagawa T, Seki H, Satoh K, Takeda A, Arai H, Sasaki H : The traditional Chinese medicine Banxia Houpo Tang improves swallowing reflex. Phytomedicine 6, 103-106 (1999)

24) Iwasaki K, Wang Q, Seki H, Satoh K, Takeda A, Arai $\mathrm{H}$, Sasaki H: The effects of the traditional Chinese medicine, "Banxia Houpo Tang (Hange-Koboku To)" on the swallowing reflex in Parkinson's disease. Phytomedicine 7, 259-263 (2000) 